\title{
A Consideration of the so-called Comfort Women Problem in Japan-Korea Relations: Embracing the Difficulties in the International Legal and Policy Debate
}

\author{
Koji Teraya*
}

The main purpose of this short essay is to mitigate harsh debate about 'comfort women.' Although it is not expected to be resolved in the foreseeable future, understanding the structure of the problem based on the fact-finding and legal analysis would enable the two peoples to seek a better solution. The author claims that: (1) although some of the historical facts remain unclear, and some people tend to focus too much attention on fact-finding, from the viewpoint of international law, sufficient evidence has been revealed to confirm Japan's responsibility for its conduct in the Second World War, and Japan does not and should not deny the relevant historical facts; (2) Japan was absolved of its responsibility by the 1965 Agreement in a legal sense; and (3) having said that, this case reveals the limits of the positivistic legal approach, and the Asian Women's Fund can be one legitimate way of dealing with this problem.

* Professor of International Law at the University of Tokyo, Japan. LL.B. (Tokyo). The author would extend the deepest appreciation to Professors Enzo Cannizzaro, Naoki Iwatsuki and Akira Kotera for their helpful comments. The author appreciates helpful comments in Ciclo di Seminari 2011/2012: Jus Cogens after "Germany v. Italy," Sapienza Università di Rome, June 11, 2012. Appreciation should be also given especially to Professor Enzo Cannizzaro and Professor Naoki Iwatsuki. The author also thanks the participants in his seminar "Theory and Practice of International Human Rights Law" at the University of Tokyo in 2012-13, and in a research meeting about international responsibility led by Prof. Akira Kotera held in March 2013. The views expressed in this article are those of the author and does not necessarily reflect the position of the Japanese government. The author accepts full responsibility for the facts and views expressed herein. Address: Building 3 of Faculty of Law, the University of Tokyo, 7-3-1 Hongo, Bukyo-ku, Tokyo, Japan 113-0033. 


\section{Keywords}

Comfort Women, State Responsibility, The 1965 Japan-Korea Agreement, Asian Women's Fund, Human Rights, Feminist Perspective

\section{Introduction}

The so-called comfort women problem is, together with the 'dispute/conflict' over 'Takeshima/Dokdo' Islands, one of the most controversial issues in relations between Japan and Korea. Those relations have deteriorated somewhat in recent times, especially since the visit of former President Lee Myung-bak to Takeshima/ Dokdo in August 2012. According to him, it was necessary to take a concrete stand in response to Japan's negative attitude towards the 'comfort women' issue in the summit meeting at the end of 2011. ${ }^{1}$ It is both surprising and regrettable that a close neighbor friend sharing common institutional values ${ }^{2}$ argues so harshly as if their wide-ranging cooperative relation should be reduced just to these nationalistic issues. The 'comfort women' issue would often stimulate nationalism in both States, but the strength of feeling on the two sides tends to make a solution unreasonably difficult to find.

The author feels hesitation in dealing with this delicate matter in a short essay such as this. He even holds the pessimistic belief that the issue will not be resolved in the near feature. Even the term 'solution' is the subject of some debate. However, the author also believes that understanding the structure of the problem based on facts and legal analysis would serve to mitigate the harshness of the current unfruitful conflict. Embracing the difficulty enables people in both states to seek a better solution.

This research focused on the issue in the Republic of Korea, because it most clearly demonstrates difficulties. This paper is composed of five parts including Introduction and Conclusion. Part two will examine the fact-finding and responsibility of Japan. Part three will analyze the 1965 Agreement relating to the 'comfort women' problem. Part four will discuss the Asian Women's Fund. Due to

1 Staff Writer, Korean President visited Takeshima and made a decision on 'comfort women' issue (available only in Japanese), THE NIKKEI, Aug. 13, 2012, available at http://www.nikkei.com/article/DGXNASGM1304L_ T10C12A8FF2000/?dg=1 (last visited on Aug. 13, 2012).

2 See Remarks of the former President Myung-bak Lee on National Liberation Day on August 15, 2012, available at http://digital.asahi.com/articles/TKY201208150147.html?ref=comkiji_txt_end (last visited on Apr. 13, 2013). 
the present author's limited language ability, most references quoted here are from sources written in Japanese, so that he would welcome any necessary additions and changes in the future.

\section{Fact-Finding and the Responsibility of Japan}

\section{A. Official Position of Japan concerning Facts}

For many people in Japan, the factual question is the core of the 'comfort women' issue. Some Japanese go so far as to say that the 'comfort women' did not exist, while other Japanese strenuously reject this negation.

It is worth mentioning the statement of Prime Minister Shinzo Abe in his first administration, which triggered bitter protests in both Japan and other countries. Responding to a question about his previous statement on the forceful seizure of 'comfort women,' he differentiated 'forcibility' in a narrow sense from that in a wide sense. In a debate in the Diet, he claimed;

There is so-called forcibility in a narrow sense and a wide sense. It is one thing to break into a house and to seize a woman forcibly. On the other hand, forcibility in a wide sense means that a woman is in a surrounding where she had to go [to a comfort station,] though she did not want to. The situation was relevant to what happened. ${ }^{3}$

By this differentiation, he tried to negate the existence of forceful seizure in what he defines as the narrow sense.

To be fair, it should be mentioned that his differentiation is not irrational. ${ }^{4}$ Abe claims that the context was concerned with re-examination of the suitable description of criminal cruelty in a junior school textbook, not to hide a historical fact. In addition, it is common, especially for lawyers, to differentiate between the narrow and the wide definitions of a term. However, this usage seems proposed by halves. If he tried to argue that there is no clear evidence that the government was directly concerned with forceful seizure in a narrow sense, though it is still controversial, he

3 See Statement in the Budget Committee of the House of Representatives on October 6, 2006 (available only in Japanese), available at http://www.shugiin.go.jp/index.nsf/html/index_kaigiroku.htm (last visited on Apr. 13, 2013).

4 His political attitude itself is another matter, which should be construed with his other comments and behavior. 
would be right. ${ }^{5}$ But it may be called "forceful seizure in the narrowest sense," if taken in the same line as his usage, which is different from "forceful seizure in a narrow sense." [Emphasis added] If he tried to negate all cases of forceful seizure in a narrow sense, he committed the mistake of making an unjustified generalization. Regardless of his clumsy usage, he clearly admitted that: "I succeed to Kono's statement as Prime Minister." The Kono's statement includes the following comments: ${ }^{7}$

As a result of the study which indicates that comfort stations were operated in extensive areas for long periods, it is apparent that there existed a great number of comfort women. Comfort stations were operated in response to the request of the military authorities of the day. The then Japanese military was, directly or indirectly, involved in the establishment and management of the comfort stations and the transfer of comfort women. The recruitment of the comfort women was conducted mainly by private recruiters who acted in response to the request of the military. The Government study has revealed that in many cases they were recruited against their own will, through coaxing coercion, etc., and that, at times, administrative/ military personnel directly took part in the recruitments. They lived in misery at comfort stations under a coercive atmosphere.... As to the origin of those comfort women who were transferred to the war areas, excluding those from Japan, those from the Korean Peninsula accounted for a large part. The Korean Peninsula was under Japanese rule in those days, and their recruitment, transfer, control, etc., were conducted generally against their will, through coaxing, coercion, etc. [Emphasis added]

\section{B. Required Facts to Examine State Responsibility of Japan}

Dealing with the status of historical facts ${ }^{8}$ can be difficult for many lawyers who, like the author, lack the necessary specialist skills to evaluate those facts. Unfortunatley, the status of 'facts' surrounding the 'comfort women' issue take central stage because these facts have often resulted in very heated debates. For instance, the Coomaraswamy Report submitted to the UN Commission on Human Rights, ${ }^{9}$ hailed

5 As illustrated later, Kono's statement acknowledges it. In any case, one does not have to stick to this point in order to examine the responsibility of Japan as discussed later.

6 Supra note 3.

7 See Statement by Chief Cabinet Secretary Yohei Kono on the Result of the Study on the Issue of 'Comfort Women,' Documents of Japanese Government and the AWF, Aug. 4, 1993, available at http:/www.awf.or.jp/e6/statement-02. html (last visited on Apr. 13, 2013).

8 See Collection of Materials Relating to the Wartime Comfort Women Issue: Government of Japan Survey, available at http://www.awf.or.jp/e6/document.html (last visited on Apr. 13, 2013).

9 R. Coomaraswamy, Report of the Special Rapporteur on Violence against Women, its Causes and Consequences 
by the victims and their supporters, has been criticized as being based on invalid proofs. ${ }^{10}$ It was criticized even by one interviewee for a misunderstanding of what he said. ${ }^{11}$ For an appropriate judgment on the controversies, however, all the facts and proofs cited must be investigated and evaluated, which is almost impossible for lawyers in general.

There also remains the intractable problem of language in the production of international reports. An investigator who is expected to be neutral would usually be unfamiliar with the languages of the relevant parties; they have even difficulties in interviews with the victims. Those who are fluent in either or both languages usually have either nationality; they are thus unlikely to possess the necessary neutral status.

However, this essay focuses more on the issue of whether Japan should take State responsibility under international law for the conduct during the Second World War than on fact-finding itself. Negation of forceful seizure in the narrow sense by Prime Minister Abe was a point at issue. From a legal perspective, however, more attention should be paid to the fact that he acknowledges forceful seizure in a wider sense, or the 'indirect' involvement of the then Japanese military (Kono's statement), because it is construed as a violation of international law enough to give rise to the responsibility of Japan. His mention was basically related only to 'recruiting' women. In this context, however, Abe does not deny the fact that the 'comfort women' system in Korea was managed by the Japanese military as an organ of Japan. He also recognizes that there were wrongful acts, as he followed to Kono's statement. Actually, no claim denies that the system was intended to provide sexual services for Japanese soldiers and maintained by the Japanese military. It is widely recognized that it was established to prevent sexual crimes of soldiers, at least in the beginning, ${ }^{12}$ a fact sometimes used in nationalistic arguments as part of a vindication of Japan's position.

(hereinafter Coomaraswamy Report). See U.N. Doc. E/CN.4/1996/53/Add.1. (Jan. 4, 1996), available at http://www. unhchr.ch/Huridocda/Huridoca.nsf/0/b6ad5f3990967f3e802566d600575fcb?Opendocument (last visited on May 1, 2013).

10 Yasuaki Onuma, "Ianfu” Mondai toha Nan Dattanoka (What was "Comfort Women" Problem?), 148-150 (Chūōkōronsha, 2007). Report by Ms. Gay J. McDougall (U.N. Doc. E/CN.4/Sub.2/1998/13, Jun. 22, 1998) is evaluated much critically. See id. at 150. Professor Tokota Yozo criticizes the excessive overestimation of the Coomaraswamy Report by media and critics, pointing out that it is just a part of a larger document concerning violence against women in the contemporary age and that it shows the Special Rapporteur's individual opinion to be discussed and was just taken note by the Commission with no binding resolution. See Yozo Yokota, 'Ianfu' Mondai to Kokuren no Jinkenhoshō (So-called 'Comfort Women' Issue and Human Rights Protection in the UN), in IANFU' MondaI TO Ала Jyosei KiKin (Comfort Women” and Asian Women’s Fund) 93-96 (Yasuaki Onuma et al. eds., 1998).

11 Ikuhiko Hata, Ianfu to Senzyo no Sei (Comfort Women and Gender in a Battle Field) 422-423 (1999).

12 Coomaraswamy Report, at 5. 
The point is that Japan was in a position to control the 'comfort stations.' As a general rule, even if a wrongful act was not directly carried out by the State, there is a responsibility for omission. ${ }^{13}$ Recent codification of international law in Articles on State Responsibility of 2001 provides this general principle in Article 2 as follows: "There is an internationally wrongful act of a State when conduct considering of an action or omission: (a) is attributable to the State under international law; and (b) constitutes a breach of an international obligation of the State." ${ }^{14}$ [Emphasis added] Any violation of international law within its jurisdiction is attributed to Japan, which managed the 'comfort women' system in Korea.

Some say that, even if it did occur, forceful seizure in a narrow sense was carried out not by the Japanese military, but by the Korean private sector. As for comfort stations, it has been pointed out that they were typically supervised by a private operator and the women were often taken care of by a Japanese or, in some cases, a Korean woman. ${ }^{15}$ However, this does not change the issue of attribution. In general, the conduct of private persons or entities is not attributable to a State. Instead, specific factual relationships between the person or entity and the State can give rise to responsibility of the State. Article 8 of the Articles on State Responsibility titled, "Conduct directed or controlled by a State," provides: "The conduct of a person or group of persons shall be considered an act of a State under international law if the person or group of persons is in fact acting on the instructions of, or under the direction or control of, that State in carrying out the conduct." There is some controversy over the meaning of "under the direction or control" of a State. ${ }^{16}$ In this case, however, the strict 'effective control' was sufficient in the conduct of Japan to give rise to international responsibility.

It is also necessary to turn an eye to substantive norms, or primary rules. Avoiding the problem of retroactive application of treaties and difficulties in proving customary international law, one can safely mention some relevant treaties to which Japan was a party at that time, such as Article 46 of the Hague Convention of 1907, the International Agreement for the Suppression of the "White Slave Traffic" of 1904, and the International Convention for the Suppression of the Traffic in Women of Full Age of 1921. There could be some interpretative issues to discuss even in these

13 William. E. Chapman (US) v. United Mexican States, R.I.A.A. (vol. IV), Oct. 24, 1930, reprinted in 1974, at 634639.

14 J. Crawford, The International Law Commission's Article on State Responsibility: Introduction, Text and Commentaries 110-112 (2002).

15 Coomaraswamy Report, at 10.

16 Supra note 14, at 82. 
treaties. ${ }^{17}$ However, it is not necessary to examine the relevant arguments, because, in any case, Japan does not contend against their binding character and instead focuses on the dissolution of its responsibility in recent international forums such as the Human Rights Committee ("HRC") and the Human Rights Council. ${ }^{18}$

It seems that some Japanese, regretfully politicians included, often go so far as to deny the historical facts about 'comfort women.' Such an attitude should be criticized, as demonstrated in international forums. ${ }^{19}$ Professor Chizuko Ueno, a prominent Japanese feminist, criticizes such revisionism, calling it "the Third Crime" following rape in the war and obliviousness for a half century after the war. ${ }^{20}$ It seems that the fault is partly caused by their emphasis that Japan dissolved its responsibility for war compensation, but fact-finding and acknowledgement of responsibility should be clearly differentiated. Mingling these two just leads to a barren argument in a narrow-minded nationalist.

\section{Legal Approach for Solving the 'Comfort Women' Problem: The 1965 Agreement}

\section{A. The 1965 Agreement as a Basis of the Argument}

The next issue is whether Japan has been absolved of its responsibilities or not. The most relevant international legal material is the Agreement on the Settlement of Problems concerning Property and Claims and on Economic Co-operation between Japan and the Republic of Korea (hereinafter the 1965 Agreement). ${ }^{21}$ Article 2(1) of the 1965 Agreement provides as follows;

The Contracting Parties confirm that [the] problem concerning property, rights

17 E.g., it is possible to raise a question whether there was a war between Japan and Korea, where the Hague Convention of 1907 can be applied. As for the 1921 Convention, the declaration of Japan matters, which reads that: It "does not include Chosen, Taiwan, the leased Territory of Kwantung, the Japanese portion of Saghalien Island and Japan's mandated territory in the South Seas." See International Convention for the Suppression of the Traffic in Women and Children, available at http://treaties.un.org/pages/ViewDetails.aspx?src=TREATY\&mtdsg_no=VII$3 \&$ chapter $=7$ \&lang $=$ en (last visited on May 1, 2013).

18 U.N. Doc. CCPR/C/JPN/Q/5/Add.1 (Oct. 1, 2008), at 24-25; U.N. Doc. CCPR/C/SR.2575 (Feb. 18, 2009), ๆ 51; U.N. Doc. A/ HRC/8/44 (May 30, 2008), ๆๆ $29 \& 45$.

19 See Remark of Ms. Wedgwood, U.N. Doc. CCPR/C/SR.2576 (Nov. 7, 2008), ๆๆ 2 \& 30.

20 Chizuko Ueno, Nashonarizumu to Jendā (Nationalism and Gender) 98-103 (Iwanami Shoten, 2012).

21 Signed in Tokyo on Jun. 22, 1965. 8473 U.N.T.S. 
and interests of the two Contracting Parties and their nationals (including juridical persons) and concerning claims between the Contracting Parties and their nationals, including those provided for in Article IV, paragraph (a) of the Treaty of Peace with Japan signed at the city of San Francisco on September 8, 1951 , is settled completely and finally. ${ }^{22}$

The author is of the opinion that Japan absolved its responsibilities towards the 'comfort women' through the 1965 Agreement. The term "completely and finally" employed in Article 2(1) seems decisive in reaching this conclusion. One cannot find this kind of clear term in the other equivalent agreements such as the 1951 San Francisco Treaty of Peace with Japan, or other agreements and declarations with Taiwan (1952), the USSR (1956), China (1972), and the DPRK (2002). It is ironic that Japan has encountered the harshest protests in the Republic of Korea, with which it concluded an agreement in such clear terms.

Textual reading of "property, rights and interests of the two Contracting Parties and their nationals" cannot exclude the rights of 'comfort women' from this scope. The right way to interpret a treaty is to read the text "in accordance with the ordinary meaning to be given to the terms of the treaty in their context" as codified in Article 31(1) of the Vienna Convention on the Law of Treaties ("VCLT"). ${ }^{23}$ As far as the text is concerned, Ms. Coomaraswamy made a simple mistake by stating that "the 1965 treaty only regulated property claims and not personal damages." 24 Also "in the light of its object and purpose, ${ }^{25}$ the conclusion is the same, because the purpose of the treaty is "to settle [the] problem concerning property of the two countries and their nationals and claims between the two countries and their nationals" ${ }^{26}$ with the phrase "completely and finally."

In addition, though it is not clear how she considers this fact in her argument, Ms. Coomaraswamy mentioned the significant fact that "[i]n March 1993, following the first public articles about the issue, the President of the Republic of Korea, Mr. Kim Young Sam, had made public assurances that the Republic of Korea would not request any material compensation with regard to the 'comfort women' issue from the Government of Japan." ${ }^{27}$ Subsequent Practice in Article 31.3 (b) of VCLT is

22 Emphasis added.

23 VCLT adopted in 1969 was not directly applied to the 1965 Agreement, but most articles of VCLT can be considered as the codification of customary international law applicable to the 1965 Agreement.

24 Coomaraswamy Report, at 20.

25 VCLT art. 31(1).

26 The 1965 Agreement pmbl.

27 Coomaraswamy Report, at 20. 
relevant as what "shall be taken into account, together with the context."

\section{B. Possible Arguments to Minimize the Significance of the $\mathbf{1 9 6 5}$ Agreement}

It seems that the 1965 Agreement does not attract the legitimate notice it deserves as a basis to argue this issue. For instance, in its concluding observations of Japan's fifth periodic report, the HRC observes: "The State party should accept legal responsibility." However, there seems no argument responding to Japan's recourse to the 1965 Agreement. ${ }^{28}$ In the following, the author attempts to examine the claims which would lead to the contrary conclusion. This attempt is made not only to vindicate his claim, but also to examine the difficulties solving this problem through a legal approach in a positivist sense.

First, one could argue that the 1965 Agreement does not cover the "comfort women' issue, so this was not settled "completely and finally" in this agreement. ${ }^{29}$ This would be a reasonable rebuttal, if one considers that the question of 'comfort women' came to prominence in the 1990s, more than two decades after the conclusion of the 1965 Agreement. However, to know what is covered by the 1965 Agreement, one has to examine its preparatory work, which is a supplementary means of interpretation as provided in Article 32 of VCLT. ${ }^{30}$

A thorough investigation by historians is essential, but one of the relevant documents is the Tainichi Baisho Chosho (Record of Request for reparations against Japan) produced by the Korean government on August 15, $1954 .^{31}$ Part III of the document considers "Personal and Property [Jintechi Butteki] Damage caused by the China-Japan War and the Pacific War" In its explanation of "personal damage' under the heading "Payments not Received by Mobilized Koreans," the document states: "The present claim is to request various payments not received under the relevant rules of the Japanese government and the rules of remuneration in each workplace, and for compensation, etc. for the suffering caused to the victims by mobilization

28 See U.N. Doc. CCPR/C/JAN/CO/5 (Dec. 18, 2008), at 7, १ 22; U.N. Doc. CCPR/C/SR.2574 (Oct. 29, 2008); U.N. Doc. CCPR/C/SR.2575 (Feb. 18, 2009); U.N. Doc. CCPR/C/SR.2576 (Nov. 7, 2008).

29 Coomaraswamy Report, at 20 \& 25.

30 It reads: "Recourse may be had to supplementary means of interpretation, including the preparatory work of the treaty and the circumstances of its conclusion, in order to confirm the meaning resulting from the application of article 31 , or to determine the meaning when the interpretation according to article 31: (a) leaves the meaning ambiguous or obscure; or (b) leads to a result which is manifestly absurd or unreasonable."

31 Toyomi Asano et al. eds., Nikkan Kokkō SeizyōKa Mondai Shiryō (Materials on the Problem of Japan-Korea Diplomatic Normalization) vol. 3 (Part of Basic Materials) 1ff. (Gendaishiryo Shuppan, 2010). 
and their bereaved families..." 32

This is still unclear, permitting other translations, and it is just a part of the whole process of the drafting. Also, no precise definition of 'comfort women' is given, and the Korean government has also recognized that the investigation was not sufficient. On the other hand, it is safe to say that the Korean government started the negotiations in the belief that this Agreement should include personal damages, and its negotiations ended up with the terms "completely and finally." Further consideration is certainly required, but these points naturally lead to the conclusion that the 1965 Agreement covers the issue of 'comfort women.' It seems quite difficult to reverse this conclusion of the textual reading and consideration of subsequent practice as mentioned above.

Second, though it seems less relevant, one should mention the established legal theory related to norms regarding invalidity and termination and suspension of operation of treaties under customary international law. Articles 42-72 of VCLT, adopted in 1969, provides a codification of customary law. Almost all the provisions, however, are irrelevant in this context. No historical fact was known, which would relate to error, fraud, corruption, coercion of the representative of State, coercion by the threat or use of force, impossibility of performance and severance of diplomatic or consular relations. Article 53 on jus cogens is relevant in that the rights of 'comfort women' could fall within the range of jus cogens. However, it seems difficult to say that relevant specific norms became jus cogens during the Second World War in the age of no positive acknowledgement of the category. ${ }^{33}$ It is also doubtful to allege it in terms of its consequence. Article 62 on the principle of rebus sic stantibus (fundamental change of circumstances) might be the most relevant, considering that the existence of 'comfort women' was not known internationally. Nonetheless, it is difficult to claim that 'comfort women' cannot be what was "not foreseen by the parties, " ${ }^{34}$ because sexual violence in emergency and war are a well-known historical phenomenon. Whether 'comfort women' was a big issue or not, they would conclude the 1965 Agreement and, in any case, neither government would ever resort to these causes whose legal consequences just lead to a destabilization of relations. $^{35}$

32 Id. at 178.

33 L. Hannikainen, Peremptory Norms (Jus Cogens) in International Law: Historical Development, Criteria, Present Status 136-145 (1988).

34 M. Shaw \& C. Fournet, Article 62, in 2 The Vienna Conventions on the Law of Treaties: A Commentary 1428 (O. Corten \& P. Klein eds., 2011).

35 As for the effect, see P. Reuter, Introduction to the Law of Treaties 191-193 (J. Mico \& P. Haggenmacher trans., 1995). 
Finally, the argument of transtemporal law is relevant, though this theory is in its infancy at best. Professor Koki Abe, one of the leading human rights scholars in Japan, criticizes the judgments of the Japanese courts concerning war compensation, invoking the perspective of transtemporal law. According to Abe, the transtemporal perspective "is not just to seek for judging the acts in the past by the present standard. Rather, its important aspect is, relying on historical perception, to find the possibility to apply the present or past refined rules in the reconstructed/refound past." ${ }^{36} \mathrm{He}$ explains that: "It is an activity neither to forge a non-existing past nor retroactively apply present standards to the past, but to recognize the existing reality again from the transtemporal perspective. Therefore, this is not a total immediate dismissal of intertemporal law, but a deconstruction." ${ }^{37}$

It is not easy to understand this post-modern idea from Abe's writing quoted above. ${ }^{38}$ He certainly opposes the retroactive application of norms to acts in the past, but it is not clear how this theory can be connected with existing jurisprudence. He simply says that the perspective of transtemporal law can weigh decisively on judgments concerning war compensation, ${ }^{39}$ but it would be strange if this postmodern idea was to be realized in the modern legal system. In addition, the need for a new theory seems to presuppose that Japan is right under the present legal system.

If one tries to realize the intent of this theory and agrees to consider facts and application of norms which are different from ordinary jurisprudence, the consequence should also be different from standard ideas such as 'reparation' in the present legal system. Separated from the modern legal attempt, the Asian Women's Fund discussed in the next section should be one of them, although Abe seems to have doubts about this project.

Before examining a moral approach to the issue, it is important to consider a point not often been raised about the consequences of concluding the 1965 Agreement. Japan's responsibility is usually at issue in this problem, which naturally leads a discussion of compensation by Japan to the victims. However, if all the above is correct, from a legal viewpoint, it is not Japan but the government of Korea, as a domestic matter, that bears the responsibility for compensating the victims. ${ }^{40}$

36 Kohki Abe, Kokusaihō no Bōryoku wo Koete (Beyond the Violence of International Law) 237 (Iwanami Shoten, 2010).

37 Id. at 238.

38 According to Abe, the term, 'transtemporal law' comes from a presentation of Professor Keun-Gwan Lee in the Forum held in 2004 under the topic, Japan-Korea Annexation Treaty of 1910. See id. at 258.

39 Id. at 238.

40 Professor Yu-Ha Park suggested this conclusion with a feminist viewpoint. See Yu-Ha PARK, WaKai no TAmENI (For Reconciliation) 148 (Hisashi Sato trans., 2011). 
Generally speaking, if State A abrogates the rights of its own nationals by concluding a treaty with State B, it is the government of State A, not State B, which has to provide compensation. This is the same as compensation in domestic public law, or matters of right of reimbursement in private law. Actually, in the Atomic Bomb case (1963), ${ }^{41}$ the defendant allegedly responsible for compensation to the victims was not the United States but the government of Japan, through the 1951 San Francisco Treaty, though the plaintiffs lost the case.

\section{A Moral Approach to the 'Comfort Women' Problem: The Asian Women's Fund}

\section{A. The Blurred Horizon of the Legal Approach}

The author believes that Japan was absolved of its legal responsibilities by concluding the 1965 Agreement. However, he is also opposed to the opinion that any recent consideration of "reparation" is just bringing up old debates meaninglessly. The importance of the role played by the legal system in ensuring society stability leads to the claim that such a reexamination is admitted only in an exceptional case. Though theorizing it in a definitive form is not the purpose of this short essay, the issue of 'comfort women' has certainly some indications to reconsider.

As discussed, each rebuttal to the legality of the Japanese position in the above discussion is not successful, but there is some reasonableness in those arguments. First, though the 1965 Agreement is construed to cover 'comfort women,' the issue was not its main object. Second, it was once accepted that States can make an agreement accompanying the abandonment of individuals' rights, but the contemporary world finds it 'injust.' There are two ways of criticizing it. One is based on the modern conception of human rights. While traditional diplomatic protection regarded individual rights as being subsumed under State interests, this system now considers human rights. ${ }^{42}$ The other is an extension of consent theory into the individual level, which means the extensive application of the spirit expressed in

41 Tokyo District Court, Judgment, Dec. 7, 1963 (Kakyū Minshū), vol.14, no.12, at 2435.

42 For details on recent changes, see Ahmadou Sadio Diallo (Guinea v. Congo), Exceptions préliminaires, 2007 C.I.J. 599, 939 (May 24). As for the general discussion on this case, see R. Mazzeshi, Impact on the Law of Diplomatic Protection, The Impact of Human Rights Law on General International Law (M. Kamminga \& M. Sceinin eds., 2009). 
Article 34 of VCLT. It is unreasonable for a third party to be able to abrogate the rights of another. It is fair to say that Japan also delivered such a decision even to its own national in the Atomic Bomb case (1963), ${ }^{43}$ but this neither changes the injustice of the traditional idea of diplomatic protection, nor vindicates the Japanese position on this issue. Third, in relation to the retroactive application of current standards to acts in the past, the 'comfort women' issue is not totally regarded as in the past, because the victims are still alive. This is not only claimed from practical relevance, but also from a doctrinal viewpoint. The 'comfort women' issue can be out of the scope of the claim that a past injustice should not be judged retroactively. One can ask whether it is justifiable to emphasize only the legal function of ensuring social stability by mentioning a treaty which does not deal specially with the topic, irrespective of the fact that new rules are emerging and some of the victims are still alive.

Maintaining the above legal claim, the author recognizes that cogency of an argument is a matter of degree. In consideration of this issue, in the fifth periodic report of Japan, Ms. Wedgewood, a member of the HRC, expressed her opinion with the remark, "[l]eaving aside the purely legal aspects of the question." ${ }^{44}$ Professor Yasuaki Onuma, an eminent international lawyer and one of the proponents of the Asian Women's Fund, criticized the former claim of the Japanese government that the issue was settled by treaties, while admitting that the argument is basically valid from the position of an international lawyer. He argues: "It is quite another whether this legal 'settlement' can bring about a peaceful and stable relationship" between the legally conflicting parties. ${ }^{45}$ In general, social needs sometimes require more than pure legal argument, basing on its legal analysis. The 'comfort women' issue is located on the blurred horizon of the legal approach, beyond which one may recognize non-legal matters such as legitimacy, justice and morality.

\section{B. The Activities of the Asian Women's Fund}

The Asian Women's Fund is the largest-scale project after the 1965 Agreement,

43 Supra note 41.

44 Supra note 19, 12 (Nov. 7, 2008). As mentioned earlier, the problem is due to the HRC's jumping up to a legal conclusion without explicit legal reasoning. See U.N. CCPR/C/JPN/CO/5, १ 22 (Apr. 13, 2010). The delicate nuance seemed lost during drafting the concluding observation. Any construction is welcome at least tentatively. Without it, the authority of the HRC as quasi-judicial organ would be hurt.

45 Yasuaki Onuma, Japanese War Guilt and Postwar Responsibilities of Japan, 20 Berkeley J. InT’L L. 613-614 (2002). 
which should be examined in the horizon of the legal approach. ${ }^{46}$ In 1991, a Korean woman confessed herself as a former 'comfort women' and, with others, brought a case to the Tokyo District Court. This was so sensational that the then Miyazawa administration had to launch an investigation which resulted in Kono's statement issued in 1993. However, no projects for the victims were conducted by the following two administrations, dominated by the Liberal Democratic Party ("LDP”). In 1994, a coalition government was established, headed by Tomiichi Murayama, the leader of the Japan Socialist Party ("JSP"; now the Social Democratic Party). It emphasized human rights more than the LDP based on a delicate balance. However, the proponents of the Asian Women's Fund found it the only opportunity to realize projects for the victims. The Fund was established in 1995 and launched its projects in 1996 under the subsequent Hashimoto administration.

The project of the Asian Women's Fund consisted of the following five activities: (1) atonement from the Japanese people; (2) a letter from the Prime Minister of Japan; (3) medical Welfare Assistance Projects; (4) a letter from the President of the Asian Women's Fund; and (5) messages from Japanese contributors. ${ }^{47}$

The first two projects are the more significant. As for atonement from the Japanese people, the Asian Women's Fund intended that: “The money contributed by the Japanese people is to be used in an attempt to express to the former 'comfort women' our sense of moral responsibility and sincere apologies and remorse for what was done in our name." ${ }^{48}$ The amount of atonement money was to be two million yen per person, while the amount of medical welfare assistance was to be differentiated according to price levels in each country. ${ }^{49}$

As for the letter from the Prime Minister of Japan, the Fund announced that: "The government of Japan...has publicly expressed its sincere apologies and remorse." The letter was signed Ryutaro Hashimoto, with the title of "Prime Minister of Japan," and reads:

The issue of comfort women, with an involvement of the Japanese military authorities at that time, was a grave affront to the honor and dignity of large numbers of women. As Prime Minister of Japan, I thus extend anew my most

46 Historical explanation about Japan after the Second World War serves to clearer understanding of the Fund. See id. at 604-610.

47 See Zyosei no tame no Azia Heiwa Kokumin Kikin [Pamphlet for the Asian Women's Fund] 9 (1997), available at http://www.awf.or.jp/2/index.html (last visited on May 1, 2013).

48 Id.

49 Supra note 10, at 42-44.

$50 \quad$ Supra note 47. 
sincere apologies and remorse to all the women who underwent immeasurable and painful experiences and suffered incurable physical and psychological wounds as comfort women....

The Fund dissolved in May 2007. Up until then, 364 victims received atonements and letters. ${ }^{52}$ It was reported that: "All of the approximately 565 million yen from citizen donations were used as compensation. Approximately 750 million yen from government funds went to medical welfare support. ${ }^{\text {"53 }}$ The government contributed a total of approximately 4.8 billion yen from the national budget. ${ }^{54}$

\section{Analytical Points of the Asian Women's Fund}

\section{Relevance of the Fund to Legal Evaluation in the International Forums}

The Fund has been acclaimed as a moral-based project, but this does not mean that it is not subject to legal scrutiny.

The HRC, the supervisory body of the International Covenant on Civil and Political Rights, does make an evaluation of the Asian Women's Fund project. In its most recent concluding observations in consideration of the fifth periodic report submitted by Japan, "[ $t$ ]he Committee notes with concern ...that the compensation provided to victims is financed by private donations rather than public funds and is insufficient, ...." Even this short line raises the following questions: Does it sufficiently recognize that the Asian Women's Funds is also financed by the government? What is the HRC's evaluation concerning the letter from the prime minister? However, the point here is, as a prerequisite mater, that the HRC is in any case making a comment on the Asian Women's Fund. As the Japanese government rightly argues in the prior replies to the list of issues, ${ }^{56}$ the Covenant cannot apply retroactively to issues that arose before 1979, when Japan acceded to the Covenant. It is not clear how the HRC responds to this question, but the point seems to be

$51 \quad I d$. at 11.

52 Onuma, supra note 10 , at 80 . The number of receivers is not publicized county by country. The Fund intended to protect the receiver' privacy, considering that there are strong opposition to the reception from the Fund in some areas especially in Republic of Korea. See also Remarks of Onuma and Hata in 'Zyugun Ianfu': Okizarini Sareta Shinjitsu (Comfort Women: the Truth Left Behind) [Discussion], 39(7) Sнокun 35-36 (2007).

53 See The Statement by President of the Asian Women's Fund at the Final Press Conference, Mar. 2, 2007, available at http://www.awf.or.jp/e3/dissolution.html (last visited on May 1, 2013).

54 See U.N. Doc. CCPR/C/JPN/Q/5/Add.1, at 24 (Oct. 1, 2008); U.N. Doc. A/HRC/8/44, 945 (May 30, 2008).

55 U.N. Doc. CCPR/C/JPN/CO/5, ๆ 22 (Apr. 13, 2010).

56 Id. Add. 1, 1, at 24. See also U.N. Doc. CCPR/C/SR.2575, १ 51 (Feb. 18, 2009), available at http://www.bayefsky. com/summary/japan_ccpr_c_sr2575_2008_fr.pdf (last visited on May 1, 2013). 
recognized in the remark of Ms. Wedgewood mentioned before. ${ }^{57}$ Whether good or bad seems to reflect the quasi legal character of this organ. In any case, the argument was going on "with this as a premise" from the viewpoint of Japan. Namely, Japan maintains the position that the ICCPR does not apply retroactively so that legal analysis may be meaningful, maintaining relevance to the real conflict.

A similar situation is found in the Universal Periodic Review ("UPR") by the Human Rights Council created in 2006. In the review of Japan, some members of the Council such as North and South Korea, and France took up the "comfort women' issue. Japan responded to their comments, explaining the projects of the Asian Women's Fund. ${ }^{58}$ However non-judicial the dialogue looks, it remains within the scope of a legal process from an institutional viewpoint, because the basis of the review is international legal materials: the UN Charter, the Universal Declaration of Human Rights, human rights instruments to which a State is a party, voluntary pledges and commitments made by States and applicable international human rights law. ${ }^{59}$ It is thus relevant to examine the Asian Women's Fund in terms of international legal norms.

\section{The Hybrid Character of the Fund}

The Asian Women's Fund has a hybrid character, involving both the Japanese government and the private sector. The latter can be paraphrased by the Japanese national or the Japanese civil society. The Fund's official name in Japanese is Jyosei no tame no Ajia Heiwa Kokumin Kikin, which can be translated literally as "Asian Peace National Fund for Women" [Emphasis added]. ${ }^{60}$ Onuma emphasizes the importance of national participation distinct from the Japanese government. Opposing the idea of compensation by the Japanese government solely based on tax without national participation, he argues that such compensation would "be immediately forgotten by most nationals, regarding it as 'somebody else's problem." ${ }^{\prime 61}$ This is well reflected by the moral character of the Fund and even its intended educational function.

Two points should be mentioned here. The first concerns the reality of national participation. It is understandable to hope that more Japanese recognize this as an issue that concerns them directly, especially considering that acts of States have

7 Supra note 19.

58 U.N. Doc. A HRC/8/44, ๆๆ 15, 26, 29, 37 \& 45 (May 30, 2008).

59 U.N. Doc. A/HRC/5/1, ch. I, 11 (Jun. 18, 2007).

60 'Kokumin' is usually translated as 'nationals.' In his paper in English, Onuma uses the terms, "the Japanese people" and 'the citizens,' rather than 'Japanese nationals.' See supra note 45, at 607 . The translation is reflected by how one sees the Fund, which raises theoretical interest in representation.

61 Supra note 10, at 19. 
frequently been performed with no engagement of their nationals. However, even if this intension is one of sincere attitudes to tackle this problem, it raises some questions: How can the proponents and the contributors represent the Japanese nation as a whole? For Japanese who do not share the attitude, this project is simply what some people want to do. The Fund's achievements are also threatened by some claims that they are unnecessary and redundant given the 1965 Agreement. Although Onuma rightly criticizes the idea limiting "nation and publicity" to "government and bureaucracy," ${ }^{2}$ this does not change the unrealistic character of national participation. Ueno criticizes this way as "a political ideal which cannot be achieved in reality. ${ }^{\prime 63}$ To summarize, there may be little need for educational effect to the people who make a voluntary donation, and there may be little educational effect on the people who regard the Fund as somebody else's problem.

The other point is the hybrid character of the Fund. Ueno does accept the importance of civil engagement, but she believes that a private fund should be established by a true NGO, with no government's engagement. ${ }^{64}$ She criticizes the Asian Women's Fund, arguing that: (1) the subject of responsibility cannot be clarified due to the Fund's vague character; (2) there is thus the possibility of the Fund being used as a pretext not to make compensation; and (3) the expression "the responsibility of nationals as a whole" will reproduce the situation, "everybody's fault is nobody's fault" which was criticized just World War II. ${ }^{65}$ The Coomaraswamy Report is even more critical on this point without showing any approval for the involvement of civil society. Ms. Coomaraswamy seems to accept the Korean NGO's idea that the Fund is a way for the Japanese government to evade its State responsibility by soliciting funds from private sources. ${ }^{66}$ This seems to put too bad a construction on the position of the Fund, but it is also true that this construction demonstrates the difficulty of understanding the Fund's hybrid character. One could thus agree with Ueno's claims on the separation of government and NGO, considering that helping the older victims financially can also be achieved in this form. However, it should be kept in mind that atonement is not the only project of the Fund. This idea should be thus examined with the other means of the Fund to fulfill its responsibility, as discussed below.

62 Id. at 195-202.

63 Supra note 20 , at $98-103$.

64 Id. at 321.

65 Id. at 214-215.

66 Coomaraswamy Report, at 21 \& 31 . 


\section{The Means of Absolution of Responsibility}

As for the means of absolution of responsibility or the consequences of responsibility, some patterns generally arise in international documents such as the Draft Articles including cessation and non-repetition, ${ }^{67}$ reparation ${ }^{68}$ in the form of restitution, ${ }^{69}$ compensation, ${ }^{70}$ and satisfaction. ${ }^{71}$ These codifications of customary international law may provide a template for consideration of this issue, though, again, we must bear in mind that there should be a limit to the legalistic analysis of the Fund. Among these patterns, 'compensation' and 'satisfaction' are the most relevant to the present issue.

It is worth reconfirming that monetary compensation is the principal means of reparation, because some argue that 'comfort women' should not receive money. Emphasizing the moral character is not irrational in this issue. In the standard understanding of law of State responsibility, however, restitution is the primary form of reparations, compensation is the second, and satisfaction is the third, because the text reads that compensation becomes an obligation, "insofar as such damage is not made good by restitution" ${ }^{\text {"2 }}$ and satisfaction is required "insofar as it cannot be made good by restitution or compensation. ${ }^{73}$ The fact that an apology is an indispensable form to the making of reparation in this problem does not change this basic framework. The importance of compensation cannot be denied. Preventing the victims from receiving monetary compensation cannot be justified, especially given the fact that they are old and in need of money in general, as Onuma argues. ${ }^{74}$

It should be mentioned that this mistakenly 'moral' twist is mainly caused by some Japanese malicious claims that all the 'comfort women' were lawful prostitutes. There is a fear that receiving money from the Fund would seem to confirm this claim. This misunderstanding is also found on the Korean side, which required the victims not to receive monetary compensation. In this respect, Professor $\mathrm{Yu}-\mathrm{Ha}$ Park harshly criticized both the Korean government and the Korean Council for the Comfort Women under the heading of the violence of "Justice, ${ }^{, 75}$ and the

67 The Articles on State Responsibility art. 30

68 Id. art. 31.

69 Id. art. 35.

70 Id. art. 36.

71 Id. art. 37.

72 The Articles on State Responsibility art. 36.1.

73 Id. art. 37.1. For details, see supra note 14, at 218-219 \& 231; Affaire relative a l'Usine de Chorzów, Fond, 1928 P.C.I.J. 47 (série A) no.17 (Sept. 13).

74 Onuma, supra note 10, at 87-108.

75 Supra note 40, at 107-109. 
Japanese government and NGOs.

Another matter is who should provide money for the victims. As mentioned earlier, if Japan was dissolved of its responsibility by the 1965 Agreement, then, the matter is a domestic issue for Korea. However, this does not preclude 'compensation' to the victims from Japan.

The next form to be examined is satisfaction which "may consist in an acknowledgement of the breach, an expression of regret, a formal apology or another modality." ${ }^{76}$

An acknowledgement of the breach has already been discussed earlier in relation to fact-finding. Here, "an expression of regret" and "a formal apology" should be discussed. In the project of the Fund, the letter of Prime Minister was sent to the victims. One of the issues was about the 'formal' character of the letter, raising a question as to whether Prime Minister Hashimoto's apology was official or private. With accusations that the Asian Women's Fund was merely a maneuver by Japan to escape from its legal responsibility, the assumption that Prime Minister Hashimoto's was a private apology comes from the fact that the letter frequently uses the pronoun 'I' and, more clearly, it states, "I wish to express my personal feelings" in the first paragraph. ${ }^{77}$ However, this seems an unreasonable accusation. ${ }^{78}$ If Hashimoto's real intension was to make a private apology, he would neither give his title at the bottom of the letter, nor choose the framework of the Asian Women's Fund. Instead, Hashimoto would apologize to the victims in a private manner. His hesitation to write the letter was so great that one of the influential proponents resigned in protest, which would not happen if the letter were merely private. ${ }^{79}$ It should also be mentioned that he chaired and received strong support from the right-wing Japan War-Bereaved Families Association. He was not in a position to apologize at will without considering far-reaching consequences. In addition, this letter was also signed by the subsequent Prime Ministers: Keizo Obuchi, Yoshiro Mori, and Junichiro Koizumi. ${ }^{80}$ In short, the significance of a letter signed with the title of Prime Minister cannot be over-stated. It is thus inappropriate to focus superficially on the words which seem to indicate its private character. ${ }^{81}$

76 The Articles on State Responsibility art. 37.

77 See the Hashimoto's Letter, available at http://www.mofa.go.jp/policy/women/fund/state9507.html (last visited on May 1, 2013).

78 Supra note 10 , at $180-195$.

79 Id. at $37 \& 187$.

80 See Establishment of the AW Fund, and the basic concept of its projects, available at http://www.awf.or.jp/e2/ foundation-02.html (last visited on May 1, 2013).

81 It should be mentioned that this wording problem was partly caused by the clumsiness of the translation by Japanese 
This issue leads us back to the question of the public character of the Asian Women's Fund. The Prime Minister's letter could not have been delivered if the Fund were purely non-governmental. This letter seems at the core of the Fund, as well as being a practical pillar to compensate and support the victims in a financial manner.

An official letter should play an important role in dispelling the obsessive sense of mistrust over the sincerity of the apology. It is natural that the victims have such a feeling, but, at the same time, a complete apology by every Japanese national is not only an excessive requirement, but also a practical impossibility. In the face of the controversy over the manner of compensation and even over the existence of 'comfort women,' it is impossible to unite the opinions of all nationals. How the atonement is expressed is rightly emphasized, including the requirement of delivery by hand. ${ }^{82}$ One could, however, continue to doubt the true mind of those offering the apology; asking a 'true' apology from Korea would be endless, causing frustration on the Japanese side. ${ }^{83}$ There should be some kind of limit as expressed for instance in Article 37.3 of the Draft Articles. ${ }^{84}$ One cannot require too high a standard of apology. What is reasonably required would seem to be consistent behavior of Japan as a State and its representatives in the official sphere. In this respect, the letter of the Prime Mister is indeed significant.

Two points should be added concerning general issues common to compensation and satisfaction. First, whether the Asian Women's Fund is what the 'comfort women' really hope for. It relates to how the State responsibility is regarded in a theoretical framework. Under the strong influence of Anzilotti who criticized the distinction between civil and criminal responsibility in international law, denying the latter, ${ }^{85}$ one of the dominant ideas has been that "reparation must, as far as possible, wipe out all the consequences of the illegal act and reestablish the situation which would, in all probability, have existed if that act had not been committed." ${ }^{86}$ In this understanding, the form of reparation cannot be decided solely by the side of instigator of the offence. This is in accord with Ueno's criticism that the Asian Women's Fund is not what 'comfort women' want, and has led to serious divisions

side. This kind of problem is also pointed out on choosing a Korean word 'apology.' See Onuma, supra note 10, at 63-64.

85 D. Anzilotti, Cours de droit international 468 (Panthéon-Assas ed., 1999; G. Gidel, trans., 1929). See also supra note 14 , at 78 .

86 Supra note 73 , at 47. 
among the victims. ${ }^{87}$

Second, means of absolution of international responsibility can be differentiated, depending on the relations of the relevant entities. In this case, compensation and apology can be independent. After the 1965 Agreement, as the author believes, the provision of monetary compensation to the victims should be considered an internal matter for the Korean government. However, the question arises as to whether this implies that Japan does not have to make an apology to the victims. The Articles on State Responsibility naturally apply to the situation of Japan-Korea relations in 1965. Presupposing two entities, the Draft Articles provide forms to absolve responsibility as a continuous enumeration, regarding apology as optional "insofar as it cannot be made good by restitution or compensation. ${ }^{88}$ However, it seems improper to apply this idea without some necessary changes. A situation could arise where both sides think that the other side's request is too demanding, because all the forms are proposed as a set. As a result, the victims would come to be buried between the two States.

\section{No Relation with Lawsuits}

Much attention should be paid to the relation with present or future judicial action. This Fund took the policy that it did not prohibit the victims from receiving compensation and apology by bringing the issue to courts. The position of the Japanese government is as follows: ${ }^{89}$

(a) Atonement money provided by the Asian Women's Fund is an expression of the feeling of atonement of the vast majority of Japanese people. The money is obtained through the AWF's campaigns to raise donations, and through its various activities to encourage the awareness and understanding of the Japanese people regarding the wartime comfort women issue, in order to fulfill moral responsibility.

(b) Therefore, it is the opinion of the Japanese Government that atonement money from the Asian Women's Fund is a matter which is set apart from legal issues, and that the acceptance of atonement money does not prevent that individual

87 See Remarks of Chizuko Ueno, in Symposium: 'Ianfu' Mondai Saikō (Rethinking the issue of 'Comfort Women') Proceedings, Feb. 2004, at 122-123 \& 129.

88 The Articles on State Responsibility art. 37.1.

89 See The Legal Position of the Japanese Government Regarding Implications of Acceptance of Support from Asian Women's Fund Projects (Memorandum from Bunbei Hara, President of the Asian Women's Fund), Oct. 1996, available at http://www.awf.or.jp/e6/statement-16.html (last visited on May 1, 2013). 
from instigating a lawsuit or demanding a decision with regard to that issue in a Japanese court of law.

Considering the Fund a welcome beginning, the Coomaraswamy Report emphasizes that the Fund does not vindicate the legal claims of 'comfort women' under public international law..$^{90}$ This means that both the Coomaraswamy Report and the Fund distinguish legal responsibility from moral responsibility.

This policy would give the impression that the project would serve to nothing to solve this problem. Especially for those Japanese opposed to the project, this policy serves merely to confirm the existence of the problem and to give money to the victims while leaving the present lawsuits as they are and without preventing future lawsuits.

The evaluation of this policy depends on how the purpose of this Fund is identified. For the proponents, it is a necessary policy in order to ask the victim to accept monetary compensation without fear that there is any legal connotation in conducting a lawsuit. Without this policy, the victims would face even more strongly in Korea. As a matter of fact, even with this policy, almost all victims in Korea did not receive the money. Also for the Japanese government, this policy must be favorable because the Fund would be inconsistent if it had any implications for the lawsuits. The Japanese government takes the position that this problem has already been settled "completely and finally." If the Fund would require the prevention of future lawsuits, it would presuppose that the 1965 Agreement has not finished solving the problem. From this viewpoint, branding the Fund as a moral project is important for the Japanese government to maintain its consistency. In turn, however, it raises the unfortunate criticism that Japan does not sincerely - legally in this context - make an apology. Here exists a twist, leading to the opinion that nothing should be done even if the project serves to the benefit of the victim. Such a feeling is getting stronger, as one thinks more firmly that the issue has been resolved in a legal sense.

Overall, this policy seems reflected by the sincerity of the Fund. If there were any mistake, it lay not in the moral aspect but in the practical position in the sense that the very purity made the Fund underestimate the side-effects in the political scene. ${ }^{91}$

90 Coomaraswamy Report, at 28-31.

91 Shunsuke Tsurumi, one of the proponents of the Fund, commented that they did not foresee the difficulties of delivering atonement to the victims. See Shunsuke Tsurumi et al, Sensō ga Nokoshitamono (Things War Left) 77 (Shinyōsha, 2004). 


\section{Evaluation of the Asian Women's Fund}

\section{Competing Criteria for Evaluation}

As for the evaluation of the Asian Women's Fund, the first point is to identify the beneficiary for whom the Fund has been a success or failure. It has been pointed out that the evaluation is different in the five countries and areas where the projects were operated. In the Philippines and the Netherlands, the projects were regarded as successful, while in Taiwan, the Fund's success was limited as it faced more hurdles. In Indonesia, it was regarded as a failure, but in the sense that it was made less meaningful by failings in identifying 'comfort women.' This failure was different from that in South Korea. These facts suggest that any claim is misleading if it regards the Fund's projects in various places as a whole. In this relation, it should be remembered that the Coomaraswamy Report is based on her visit only to North and South Korea and Japan. ${ }^{92}$ Her criticism cannot be generalized to other areas where the Fund gained more success. This is also true in the concluding observations of the HRC which evaluates the question without mentioning any specific area. ${ }^{93}$ Successful operation in some areas suggests that the results do not depend on the intrinsic nature of the Fund, but on the particular surroundings of the projects in each country.

The variety of surroundings must be a response to Ueno's criticism that the Asian Women's Fund is not what the 'comfort women' want. Defending the Fund, Onuma emphasizes the variety of victims: Some of them are happy to receive money, while others sincerely hope for Japan's 'official' apology and compensation. Their positions are sometimes changing and it is difficult to know their real feelings. ${ }^{94}$ This response is appropriate in terms not only of our daily experience, but of the very fact that the movement supporting the victims was divided in the face of the Fund. If it was really not wanted by the victims, unity would have been maintained. The final judgment thus depends on a comparison of the merits of what the victims accepting the Fund actually gained from these projects and the loss of what the victims refusing the Fund could possibly gain in the future if the Fund did not exist. It is thus extremely difficult to reach a conclusion, even if history reveals more relevant facts in the future.

Second, the criteria for evaluating the Fund are also relevant. Emphasis on the victims' reception of atonement and letters from a victims-centered perspective

\footnotetext{
Coomaraswamy Report, at 34-37 (Annex).

U.N. Doc. CCPR/C/JAN/CO/5 (Dec. 18, 2008), at 7, 922.

Supra note 10, at 84-100. See also supra note 40, at 132.
} 
would lead Fund to be considered more successful as more people accept them. However, other elements such as social stability can also be criteria. Again, comparison with different values is difficult.

Irrespective of the variety of possible criteria, one is inclined to say that the Asian Women's Fund in Korea has failed even from its proponents' perspective. The HRC observes that any apology should be acceptable to "the majority of victims," 95 which begs the question of degree, but failure must be an inescapable evaluation, because the number of the victims accepting the atonement and letter is too small. They were harshly criticized in Korean society; the projects brought about serious divisions within the movement. ${ }^{96}$

However, it should be mentioned that, at the request of the Korean Council for the Women, the most active Korean NGO on this issue, the Korean government took the opposing policy of promising life assistance for the victims and delivering equivalent money, under the condition of signing a written pledge not to accept atonement from the Asian Women's Fund. It is rather ironic that the Fund was partly successful in achieving its purpose of providing money to the elderly victims who had economic difficulties, though this was not through the intended process.

\section{Overall Evaluation and the Role of State}

The author is not sure that the Asian Women's Fund was the best policy for solving the 'comfort women' problem after the 1965 Agreement. Taking into account all the relevant issues, however, he feels safe to oppose the idea that the Fund is meaningless or just a pretext for Japan not to compensate. There were two possible routes other than the Asian Women's Fund. One was to wait for Japanese courts to change their jurisprudence, whether or not they introduced a new theory, as Kohki Abe hoped. However, this is still unlikely to happen. The other was to introduce special legislation to compensate the victims. Actually, this is still an option urged by, e.g., Ueno and the HRC. ${ }^{97}$ The HRC made a concluding observation that Japan should "take immediate and effective legislative and administrative measures to compensate adequately all survivors as a matter of right." 98 This must be the 'best' solution in terms of morality and clarity. The author endorses this option personally.

95 Supra note 92.

96 Onuma, supra note 10, at 53-67. Seven victims were known to accept the atonement in January 1997 and four victims were refused to receive the money by the Korean government as they were regarded to accept the atonement from the Asian Women's Fund.

97 See supra note 20, at 320-322; supra note 92. Supra note 19, 130.

98 Id. 
Practically, however, special legislation by the Diet is difficult, especially when the political situation seems much worse than it was in the middle of the 1990s. ${ }^{99}$ Even from a normative viewpoint, special legislation is not necessarily required, because legal norms indicate an end to this issue. With a general respect to the HRC, it is not without doubt that the HRC discussed these circumstances and normative considerations. Therefore, the Asian Women's Fund seemed a realistic option within legal margins to remain consistent with Japan's position on the 1965 Agreement. Onuma emphasizes the significance of national participation, but, as far as this intention, it is too idealistic. The Fund could not change its character as the second option. It has been totally successful for the people who wished to make a contribution, but success in the national participation of the Fund is limited and not crucial. In addition, it is not unreasonable to raise the criticism that the Fund appears as a Machiavellian tool to maneuver the public and the private spheres. On the other hand, as a moral project, it is quite similar to 'ordinary' legal means of absolving responsibility. Among the projects, the clear apology of Prime Ministers seems the most important, which no former NGO movements could provide.

This conclusion should be further endorsed in that the Fund adopted a policy of not preventing the victims from seeking for judicial remedy and receiving possible compensation in the future. This is mostly influenced by a human rights-centered approach. It is regretful that a Korean NGO and the Korean government brought the issue back to the relations between States. The Korean government did not pay seven victims who had accepted atonement from the Fund in 1997 and four victims who did not sign the written pledge. From the position of the victims, even the Korean government and others should be regarded as a third party. Their patriarchal character is revealed incontestably by the feminist analyses provided by the works of Ueno and Park. If one is motivated by nationalism and stuck to the framework to regard it as the inter-State issue, the 1965 Agreement remains the complete and final answer. If it is right to think that the Korean government abrogated the victims' rights by concluding the 1965 Agreement, it is not the Japanese government but the Korean government which should be obliged to compensate the victims. This should not be confused by the fact that Japan remained in the position to make an apology. The possible confusion between the two seems partly due to inefficient elaboration of international legal studies just to enumerate forms to absolve responsibility.

99 For details on the legislation in the Diet, see Attempts at legislation in the Japanese Diet, available at http://www. awf.or.jp/e4/legislation.htm (last visited on May 1, 2013). 


\section{Conclusion}

The main purpose of this short essay is to mitigate the harshness of the debate about 'comfort women' which, the author is afraid, will not be resolved in the foreseeable future. A number of factors make such political issues hard to resolve, especially an exclusivist and misleading 'patriotism' in both States. The cogency of each claim in this debate is a matter of degree; the only way to start is with an understanding of others' claims and to embrace the difficulty of this problem.

The author claims that: (1) although some of the historical facts remain unclear, and some people tend to focus too much attention on fact-finding, from the viewpoint of international law, sufficient evidence has been revealed to confirm Japan's responsibility for its conduct in the Second World War, and Japan does not and should not deny the relevant historical facts; (2) Japan was absolved of its responsibility, in a legal sense, by the 1965 Agreement; and (3) this case reveals the limits of the positivistic legal approach, and the Asian Women's Fund can be one legitimate way of dealing with this problem.

With respect to various other arguments, this paper cannot hide its strong opposition to the idea of dealing with this problem solely between States. ${ }^{100}$ That is why the author cannot agree with the argument that the issue is resolved solely by the 1965 Agreement, and why he also criticizes the response of some of Korea's policy towards the Asian Women's Fund. Not only counterposing Japan and Korea, one has to pay attention to other relations between both governments and individuals (the human rights perspective), and between men and women (the feminist perspective).

In general, the present author might appear to favor the position of Japanese nationals and the Japanese government. This short essay is written from the viewpoint of an academic, but whatever bias there may be, would be the result of my being Japanese and the limited information available in Japanese.

\footnotetext{
100 President Myung-bak Lee on the National Liberation Day (Aug. 15, 2012) made a statement to regard the issue "a breach of women's rights committed during wartime, as well as a violation of universal human rights and historic justice." As far as the text concerned, the author shares the same direction with reservation about transtemporal connotation of 'historic justice.' See the statement of President Myung-bak Lee on the National Liberation Day, available at http://digital.asahi.com/articles/TKY201208150147.html?ref=comkiji_txt_end (last visited on Aug. 15, 2012).
} 